\title{
THE IMPACTS OF COVID-19 PANDEMIC ON BUSINESSES AND ECONOMIES: GLOBAL PERSPECTIVES
}

\begin{abstract}
Different types of industries and businesses are directly and indirectly affected by the coronavirus. The economies of different countries were damaged severely; and the overall performance of such economies gets stepped backward for almost 20 years in terms of growth and development. The aim of the study is to analyze and evaluate the overall impact of the coronavirus pandemic on different types of industries and economies from a global perspective. For the analysis, the secondary sources of data is used which includes different types of articles, research papers, books, and reports published by the authors of different countries. This paper concludes that several types of business functions got severely hampered but there are some types of businesses which had gained advantages in terms of business functionality and scope. Different types of industries encountered different types of situations; most of the businesses had faced extremely bad situations whereas some from the healthcare industry such as, sanitizer, and mask manufacturing, and e-commerce-based businesses gained huge advantages.
\end{abstract}

Key Words: Coronavirus, Pandemic, Industries, Businesses, Impact

\section{Shubham Parsoya}

Research Scholar, Sangam University

\author{
Asif Perwej \\ Associate Professor, Sangam University
}

Correspondence: Chhagan Lal Parsoya

2-F-16, New Housing Board, Shastri Nagar, Bhilwara, Rajasthan, Pin Code: 311001

E-mail: parasgurushubham641@gmail.com 


\section{INTRODUCTION}

The success of any business and economy totally depends on the efficient utilization of the available resources in fulfilling the market demands. But there are several factors that play a major role in generating the favouring business environment which facilitate the functionality of creating business values and maximizing productivity. The external environment of any business and the external factors that affects the functionalities of businesses are significant to promote productivity in business tasks and projects. There are several types of problems which do come in between the path of attending the two points of businesses and economy of production and the fulfilment of the demands of people. In the current situation, the most prevalent problem to the businesses and economies is the outbreak of the pandemic.

With around 190 nations, the world functionality was seriously hampered because of the lockdown situation created by the coronavirus pandemic. And in term it seriously disturb the overall business and economic surroundings. Moreover, it also has created several types of financial complexities which will generate several other business problems and issues for the operations of different types of businesses. The spread of coronavirus significantly impacted the business operations around the world and deteriorated the economic conditions of many countries; many are facing a considerable level of slowing down of the economic growth. All around the world, people seriously faced the challenges derived from the pandemic. And such problematic situations were not tolerable especially for some vulnerable people who are at the risk of losing their jobs. Many people also had lost their lives to the spread of this harmful virus, whereas millions of them were hospitalized.

To safeguard the people from the crisis, several countries' governments declared lockdown for months. But due to the lockdown, the overall human living cost is significantly increased by manifold. And the prices of many necessity goods, such as food and water, increased rapidly, which are unbearable for some people around the world. Due to the lockdown, the business functionality also got seriously hampered and the various had to bear the extensive losses because of the complete shutdown of some industries and businesses for a series of months (during the periods of lockdown). And as we all know that the business operators are direct employment providers for a large amount of population. However, because of the lockdown situation, the employability and the livelihood earnings 
of many people got seriously hampered and disturbed, as the industries, which were giving daily livelihood to such people, were shut down for a long period of time.

Because of COVID-19, the government of different countries followed the lockdown mechanism to safeguard the lives of the people from the harmful effect of pandemic and such mechanism helps a lot to break the chain of the spreading of such harmful virus, as the government targeted primarily for making proper check over the spreading of coronavirus and then after focusing toward all the other issues (related to economy and others) coming in the way. Because, it is very important for every country to take some concrete actions for making a control over the spreading of coronavirus in the shortest time possible. But on the other hand, the complete lockdown for several months of time was not good for the businesses which are significant for the supply of goods and services on a daily basis as the lockdown mechanism however shattered the overall base pillars of the businesses and economies. The global trade and the contractual agreement of businesses between several nations which are very important for national development faced a significant interruption in the exchange of goods and services between such countries.

\section{LITERATURE REVIEW}

Research conducted by Rashmi Gujarati (2020) and Öğr. Gör.Hayri Uygun (2020) with the research paper titled COVID-19: Impact on Global Economics, published with Amity Journal of Computational Science (AJCS), ISSN: 2456-6616 (Online), Volume 4, Issue 1, (Gujrati, 2020) covers up several significant issues and topics related to the impact of coronavirus pandemic on businesses and economies. As per the author's research, due to the lockdown procedure imposed by several developing and developed nations, the overall imports and exports of such countries are facing a significant level of complexities in terms of delivery of goods and services from the point of origin to the point of consumption. Due to that the industries and the countries which are totally depending upon the exports and imports of such goods and services are facing problematic situations in running their businesses.

Because of the coronavirus pandemic the overall manufacturing industry also faced new problems in continuing its production activities, and on the other hand the produced goods and services also so could not smoothly transport from one place to another because 
of the shutting down and the slowdown of overall export and import procedures. The research paper also signifies the problem faced by the tourism industry. Due to the lockdown procedures, the tour and travel mechanism of the different nations are affected significantly and many of such tourists are still facing problems in going back to their home countries in the absence of a proper channel of transportation. A lot of people who are working in such industries lost their jobs because of the lockdown and the shutdown of such Industries' manufacturing units. Because of the shutting down of several industries especially the manufacturing industries, the overall financial crisis and the cost burden on such manufacturing industries increased manifold.

Overall, the governments of several countries had revised their plans for budget allocation according to the current situation, as the large portion of government budgets which were previously invested in manufacturing industries are now invested by the government in the health care industry plans and the procedures through which the government can manage such pandemic situations caused by coronavirus. The research paper signifies the level of negative impacts prevailing upon the retail industries, hospitals, cinemas, malls, tourist destinations, manufacturing units, the education sector, and the transportation sector.

Because of the pandemic, the governments of almost every nation are facing complexities in making decisions regarding their investment priorities between the need of saving lives of the people and creating economic profits. The research paper also signifies the disturbance created by the uneven and unplanned situations taking places in the education sector including schools, universities, and colleges where the students are facing complexities in completing their educational courses and exams, as a lot of examinations were already cancelled and several types of extension have already been taken places, and therefore the students are significantly facing problematic situations in their learning and education.

The research paper also signifies the important steps taken by several industries for resuming the overall operations including the education classes through online mediums including Google Meet, Zoom, etc. Similarly, many companies are allowing their employees to work from their homes amid the implementation of the lockdown. Such adjustment strategies initiated by several industries are expected to encourage and enhance the overall marketplace of online-based education and work from the home system for office works. Such types of strategies are concrete examples of positive steps taken by industries to overcome the negative impacts of lockdowns and pandemic situations. 


\section{OBJECTIVES OF THE STUDY}

The key objectives of this research paper are as follow:

- To study and know about COVID-19 and to analyze the impacts of it on different businesses.

- To study the impacts of COVID-19 on the global economy and to analyze the negative impacts of coronavirus on several businesses, and to also study the positive impacts of coronavirus pandemic on some of the businesses and economies.

- To evaluate the impacts of COVID-19 on the social, political, and economic factors of the countries and to analyze the impacts of COVID-19 on the quality of life of people.

- To analyze the impacts of COVID-19 on the sustainable development environment of the world and to study the world trade infrastructure.

\section{SIGNIFICANCE AND PURPOSE OF THE STUDY}

For analyzing the overall impacts of the COVID-19 pandemic on the economies and the businesses of several industries, it is important to properly understand and study the overall procedures followed by different sectors in different countries, so that we all will be able to find out more appropriate solutions and the methodologies which will be used to formulate the policies and the strategies in economic difficulties. As we all know that our environment is surrounded by various types of factors that are unavoidable, and although they can never be removed, the impacts of such factors can be minimized through the practice of appropriate strategies. Therefore, it is very important for each and every organization and nation to analyze the real ways of dealing with such problems so that each and every nation will be able to take a concrete step towards it, minimizing the overall negative impacts.

This study was conducted on the topic, "The Impacts of COVID-19 Pandemic on Businesses and Economies: Global Perspectives", which deals with all such study and indepth analysis of different factors and different ways to evaluate the overall impacts of COVID-19 on different types of businesses and economies. With the proper study and analysis of any problem like COVID-19, our world will be able to make proper strategies to take concrete steps for minimizing the overall negative impacts in the near future. 


\section{RESEARCH METHODOLOGY}

For the purpose of formulating the methodology for this research, all the useful guidelines and related principles were followed extensively, and for the quality research study of the concerned research paper titled "The Impacts of COVID-19 Pandemic on Businesses and Economies: Global Perspectives", thorough literature based upon the concerned topic was studied for the purpose of proper analysis and the evaluation. For the in-depth analysis of the stated topic and for obtaining the desired level of information, all the useful studies which are related to the topic and were published from January 2005 to March 2021 were selected. The main objective of selecting such extensively elaborated information-based data is to take helpful steps in reflecting the practices and the policies which were previously taken place in the situations of global recessions and pandemic conditions.

The research conducted for the research paper titled "The Impacts of COVID-19 Pandemic on Businesses and Economies: Global Perspectives" was based upon the secondary source of data which includes the computerized literature-based searches of different articles and research journals from authentic sources which include Google Scholar, ProQuest, Science Direct, MEDLINE (PubMed), Emerald Insight, published research journals, books, newspaper articles, e-books, and other useful information sources.

\section{ANALYSIS OF THE NEGATIVE IMPACTS OF COVID-19 PANDEMIC ON BUSINESSES AND ECONOMIES}

With the spread of coronavirus, the majority of the world's economies and businesses are significantly impacted and faced a very long period of shutting down due to the lockdown mechanism followed by almost all the areas and regions of the whole world. There were different types of strategies and policies adopted by different countries for the purpose of coping up with the negative impacts of COVID-19 pandemic and all such strategies and policies were proved to be efficient in safeguarding the lives of many, but on the other hand, the lockdown had severe economic costs on the business world.

As the world economy was not very well prepared for the spread of the COVID-19, almost all industries in the world were significantly hampered. The overall negative impacts of the coronavirus pandemic have ranged from the extreme decrease in the Gross Domestic Product (GDP) of many countries to the multilevel environmental and social-based issues 
across the whole world. The social-economic-based activities were completely shut down for a number of months, because of the negative impact of the coronavirus pandemic, especially on the society's health care of nations.

As per the lockdown mechanism of the government of the various countries, millions of people from different countries, who had travelled to other countries for the purposes of tourism, education, and businesses, were not allowed to travel back to their home countries without prior permission from the appropriate authority. On the other hand, the people were also not allowed to travel outside their countries and also from their homes in some extreme cases, due to which they were not able to buy their daily consumable items on a very frequent basis. Such situations were direct impact creator on the overall supply chain mechanism of the daily consumable items.

The demand and supply machinery of the daily consumable items and other significant products was significantly hampered, all because of lockdowns. Although, the overall lockdown measures proved to be a concrete step for safeguarding the lives of billions, but on the other hand, due to the shutting down of several types of industries the overall profitability of such industries and businesses were totally shattered, and it had several types of direct and indirect negative impacts upon the economy of different nations, especially the nations which heavily rely on the exports and imports of different goods and services from all around the world.

The overall education system faced significant interruptions as the overall classes were completely suspended and the students had faced several difficulties in completing their courses. The borders of the nation were shut down and no one was allowed to enter and exit across the national boundaries. On the other hand, such shutting down of boundaries generated several complexities, especially for the shipping industry businesses and the companies which were dealing in the exports and imports of such goods and services on a daily basis. The businesses of such nations were also completely destructed because of the overall unsuccessful financial management and the lack of availability of proper fund, due to the suspension of many business operations.

The transportation industries, which include the cars, trucks, train railways, shippings, and airlines, and all other fields related to such industries such as the travel industries were seriously disturbed. The travel industries were crippled as the buses and the trains were completely shut down because of the coronavirus pandemic lockdown situations, and therefore the demands of transportations of millions of people, who were previously using such services on a daily basis, plunged. 
The entertainment industry including cinemas, tour and travel, and many other functions such as hospitality industries which were significantly impacted by the coronavirus; many of such industries based infrastructures such as the hotels and lodges were completely shut down and occupied by the banking units as many of such hotels and infrastructures buildings were not able to cope up with the negative impacts of coronavirus pandemic and they were not able to pay the monthly basis instalments for the interests and loans repayments on a timely basis due to the shutting down of businesses.

Due to the shutting down of various manufacturing units which were giving employments and jobs to millions of people, the overall livelihood mechanism of such people got seriously affected and they were not able to fulfil their daily needs and wants, as several industry-based works were completely shut down and it results in extensive levels of losses which were not born effectively by such industries, many of such industries were not able to pay the salaries to the workers and to the labors who left their jobs and employments because of the lockdown situations generated by COVID-19 pandemic.

\section{ANALYSIS OF THE POSITIVE IMPACTS OF COVID-19 ON SOME OF THE BUSINESSES AND ECONOMIES}

Along with the negative impacts of the coronavirus, some of the positive effects do present in some scenarios. Apart from the business and economic point of view, the overall positive impacts of the COVID-19 pandemic on the environment and societies are also very significant. Because of the changes taking place in the working environment of different industries, the overall pollution that the operations of businesses used to generate was subdued for few months.

Such type of improvements in the environment plays a significant role in making the atmosphere and climate helpful and beneficial for the human beings as well as other organisms present on the earth. With the improvements taking place in the environment and climate, there is an extreme level of positive behavioral changes seen in the behavior pattern of people as the overall behavior patterns and the thinking dynamics of people changed in a completely different way and some type of calmness and satisfaction in the thinking level of people can easily be seen after the prevailing situations created and pandemic circumstances generated by COVID-19. 
And from the business point of view, with the introduction of the lockdown measures of several governments of the different nations, the overall education and many other administrative tasks were shifted to digitization and computer-based ones. For example, the overall educational courses and educational classes provided by the schools, colleges, and universities were completely turned into online-based teaching programs, which are now completely accepted by almost everyone and function with the help of computer technologies and the internet server in which the teachers and the students are completing their educational activities from their homes and there is no physical interaction that has to take a place in such mechanism.

The office work of the private sector, as well as the public sector, is now performed on a digital basis (Work-from-Home system). Such type of online based working system is truly beneficial and innovative for our society and the economy. As such a type of change in the working pattern has taken a place, this will surely save some costs. For the industries which are providing and managing the platforms of online-based working including Google Meet, Zoom application, etc. the pandemic provided a huge opportunity for them to expand their businesses on online-based communication. Such enhancements in digitization help such companies grow manifolds in the period of coronavirus pandemic.

With the escalation of COVID-19, the medical industries also gained huge marketbased profits as demands for medical services proliferated. Along with such medical industries, there are several different types of enhancement and growth that are also taking place in the development and extension of the chemical industries which were the priority in making alcohol-based products, are now engaging themselves in making the sanitizers which were growing extensively after the outbreak of the COVID-19 pandemic.

The mask manufacturing units are also taking advantages of an extensive level of enhancement in the overall consumption of daily-use-based masks. Not only large industries, but also some small-scale business units or even the cottage industries are also taking advantage of such emerging business opportunities. For earning a good amount of profits and for exploring huge possibilities through mask-making business, different people are engaging themselves in making the masks. In such a way there are different types of industries and the businesses that are taking an extensive level of advantages of doing their businesses which are directly fulfilling the overall needs and wants of the people after the outbreak of COVID-19 pandemic situations. And the resourcefulness of providing such essential commodities, which have achieved manifold growth after the COVID-19 pandemic situations, is also giving a better business and earning opportunities to different 
segments of the society for not only earning the profits from the business but also providing essential and useful services to the people of the whole world.

\section{CONCLUSIONS AND RECOMMENDATIONS}

Although the propensity of increase in coronavirus pandemic is extremely high, there may be chances of some level of enhancements in the growth in the number of cases. The spreading of coronavirus may not be showing any sign of slowing down, and therefore the COVID-19 is likely to continue to disrupt the overall economic activities of several nations for at least for a few more months or even for a few more years. The manufacturing industry as well as the service industry especially are present in the developing nations are facing severe difficulties in terms of managing their businesses because of the uncertainty presents.

It is still unclear whether the pandemic situations are going to unfold the financial crisis within the next couple of months or it will continually impose a substantial level of negative impacts on the global economy. Some of the nations including the United States of America, are considerably focusing on the fact that the coronavirus will potentially inflicting severe economic conditions and will impose a financial cost on the global economy. Because in the current era, where the global level interconnectedness presents, it is extremely difficult and costly for the whole world to escape the business developmental steps, for safeguarding the people from the pandemic situations. But on the other hand, if the businesses will have given complete freedom in terms of running their business in the pandemic situation freely, then there may be chances that the virus will enhance the risk of spreading in various regions.

For ascertaining the fact along with taking concrete steps in the field of making the best possible decision, the global level government bodies decided to invest and take concrete steps in terms of developing vaccines and making a plan for distribution so that the overall businesses and global level economic activities can be recovered within a shorter period with lesser destruction. After all, the outbreak of coronavirus is not showing any sign of disappearing in the near future because the complete suspension of business operations is impossible. 


\section{SCOPE FOR FURTHER STUDIES AND RESEARCH}

This study will open up scopes for further research and study in the field of analyzing the overall control mechanism followed by every nation, which consists of taking concrete steps for safeguarding the people from the negative impacts of coronavirus pandemic, and also includes the implementation of strategic policies for economic recoveries. The study will also help in analyzing the mechanism of executing the strategies that play a major role in combating the pandemic situations at the global level.

This study also provides opportunities to the future researchers to analyze the effectiveness of policy in relation to the control mechanism followed by the governments of the different nationalities and for making a comparative study between the strategy followed by the different nations for safeguarding the people of the respective nations along with formulation and implementation of strategic policies for lifting up the economic and business activities in respective nations.

This study also proposes the need to conduct further study to analyze extraordinary enhancement of the online education field and for finding out the ways through which such plan was so successful in terms of functionality. And it may also open different research scopes for ascertaining the future and prospective policies regarding the handling and controlling of all possible prospective pandemic situations like coronavirus pandemic.

\section{REFERENCES}

Agarwal, S. and A. Singh. 2020. Covid-19 and Its Impact on Indian Economy.International Journal of Trade and Commerce-ILARTC 9(1). https://doi.org/10.46333/ijtc/9/1/9.

Ahmed, P. K. and A. C. Simintiras. 1996. Conceptualizing business process re-engineering. Business Process Management Journal 2 (2): 73-92. https://doi.org/10.1108/14637159610123614.

Alfa Laval announces cost reduction program in response to Covid-19. 2020. Pump Industry Analyzt 2020 (3): 3. https://doi.org/10.1016/s1359-6128(20)30064-1.

Amburgey, A. and S. Birinci. 2020. Unintended consequences of coronavirus-related unemployment insurance tax laws. Economic Synopses 2020 (21). https://doi.org/10.20955/es.2020.21. 
Andrea Widener. 2020. Coronavirus concerns dampen chemists' economic outlook. Chemical and Engineering News: 26-27. https://doi.org/10.47287/cen-09837-feature4

Anistratenko, N. and A. Malchenko. 2020. Role of the IMF in overcoming the economic consequences of the coronavirus pandemic and restoring the pace of economic growth of the world economy. Efektyrna Ekonomika (6). https://doi.org/10.32702/2307-2105-2020.6.74.

Asgarov, S. R. 2021. China's post-coronavirus economic situation. Scientific Work 62 (01): 162-167. https://doi.org/10.36719/2663-4619/62/162-167.

Bates, A and G. Poole. 2003. Effective teaching with technology in higher education. San Francisco: Jossey Bass/Josh Wiley.

Bourne, J. R., J. C. Moore, and Sloan Consortium. 2005. Elements of quality online education: engaging communities. Needham, Ma: Sloan Consortium.

Burrow, J., B. A. Kleindl, and M. B. Becraft. 2017. Business management. Boston, Ma: SouthWestern Cengage Learning.

Chaudhary, P. and S. Kumar. 2020. Impact of covid-19 pandemic on Indian agriculture. International Journal of Trade and Commerce-ILARTC 9 (1). https://doi.org/10.46333/ijtc/9/1/8.

Cheeseman, H. R. 2005. Contemporary business and e-commerce law: legal, global, digital, and ethical environment. Upper Saddle River, N.J.: Pearson/Prentice Hall.

Deshwal, Vaishali and Vimal Kumar. 2021. Coronavirus disease (covid-19) outbreak in India. 2020. International Journal of Pharmaceutical Research 13 (01). https://doi.org/10.31838/ijpr/2021.13.01.086

Saxena, Shailendra K. 2019. Coronavirus disease 2019 (COVID-19): epidemiology, pathogenesis. 2020. S.L.: Springer Verlag, Singapor.

Covid-19: AG Industries increases ventilator filter production. 2020. Filtration Industry Analyzt (8): 2. https://doi.org/10.1016/s1365-6937(20)30216-1.

Davidson, P., R. W. Griffin, and A. Baxter. 2006. Management. Milton, Qld. John Wiley and Sons Australia.

Dooley, C. M., T. L. Ellison, M. M. Welch, M. Allen, and D. Bauer. 2016. Digital participatory pedagogy: Digital participation as a method for technology integration in curriculum. Journal of Digital Learning in Teacher Education 32 (2): 52-62.

Eagle Filters' respirators now Covid-19 certified. 2020. Filtration Industry Analyzt (8): 2-3. https://doi.org/10.1016/s1365-6937(20)30218-5. 
Elrhim, M. A. and A. Elsayed. 2020. The effect of COVID-19 spread on the e-commerce market: the case of the 5 largest e-commerce companies in the world. SSRN Electronic Journal. https://doi.org/10.2139/ssrn.3621166.

Ferrari, A. and Inderbir Singh Dhingra. 2009. India's investment climate: voices of Indian business. Washington, D.C.: World Bank.

Funke, M. and A. Tsang. 2020. The people's bank of China's response to the coronavirus pandemic: a quantitative assessment. modelling. https://doi.org/10.1016/j.econmod.2020.08.018.

Gandhi, P. A. and S. Kathirvel. 2020. Epidemiological studies on coronavirus disease 2019 pandemic in India: Too little and too late? Medical Journal Armed Forces India 76 (3): 364-365. https://doi.org/10.1016/j.mjafi.2020.05.003.

Garg, R. 2020. Effects of post COVID-19 on Indian economy. International Journal of Trade and Commerce-IIARTC 9 (1). https://doi.org/10.46333/ijtc/9/1/11.

Garza, R. L. 2010. Online education. San Francisco: Jossey-Bass.

Grundfos Foundation supports fight against Covid-19. 2020. Pump Industry Analyæt (3): 4-5. https://doi.org/10.1016/s1359-6128(20)30069-0.

Gujrati, R., and H. Uygun. 2020. Covid-19: Impact on Global Economics. Amity Journal of Computational Sciences (AJCS) 4 (1): 24-29.

Haber, N. 2020. Review 1: "Preprinting a pandemic: the role of preprints in the COVID19 pandemic." Rapid Reviews COVID-19. https://doi.org/10.21428/2e3983f5.ee267763.

Hausmann, R. 2020. Transformation of global supply chains in the manufacturing industry as a result of the coronavirus pandemic. Financial and Economic Review 19 (3): 130-153. https://doi.org/10.33893/fer.19.3.130153.

He, S. and E. Smith. 2020. Review 2: "Preprinting a pandemic: the role of preprints in the COVID-19 pandemic." Rapid Reviews COVID-19. https://doi.org/10.21428/2e3983f5.716acfed.

Jathar, G. B. and K. G. Jathar. 1957. Indian economics. London: Oxford University Press.

Joseph William Mcguire. 1963. Business and society. New York: Mcgraw-Hill.

Jung, J., J. Manley, and V. Shrestha. 2021. Coronavirus infections and deaths by poverty status: The effects of social distancing. Journal of Economic Behavior and Organization 182: 311-330. https://doi.org/10.1016/j.jebo.2020.12.019

Kanta Murali, Atul Kohli, and Christophe Jaffrelot. 2019. Business and politics in India. New York: Oxford University Press. Copyright. 
Kay, J. A. 1996. The business of economics. Oxford; New York: Oxford University Press.

Keith, L. A. and C. E. Gubellini. 1958. Business management. Mcgraw-Hill.

Laudon, K. C. 2019. E-commerce: business, technology, society. Boston; Columbus; Indianapolis: Munich Pearson.

Lisa Gueldenzoph Snyder and National Business Education Association. 2011. Online business education. Reston. Va: National Business Education Association.

Lloyd, P. and R. Dixon. 2021. Modelling the spread of the coronavirus: A view from economics. Australian Economic Review 54 (1): 36-56. https://doi.org/10.1111/14678462.12407.

Lorenzo, G. 2019. Business models for online education. Online Learning 10 (2). https://doi.org/10.24059/olj.v10i2.1765.

Mackenzie, D. 2021. COVID-19: the pandemic that never should have happened and how to stop the next one. S.L.: Hachette Books.

Madura, J. 2018. International financial management. Boston, Ma: Cengage Learning.

Manjula Bai, H. 2020. The socio-economic implications of the coronavirus pandemic (COVID-19): A review. ComFin Research 8 (4): 8-17. https://doi.org/10.34293/commerce.v8i4.3293.

Mcgreal, R. 2004. Online education using learning objects. London; New York: Routledgefalmer.

Mennecke, B. E. and T. J. Strader. 2003. Mobile commerce: technology, theory and applications. Hersey, Pa: Idea Group.

Mousa, N. 2020. What behind Coronavirus? How coronavirus affect the economic growth. Saudi Journal of Economics and Finance 04 (04): 145-148. https://doi.org/10.36348/sjef.2020.v04i04.002.

Noel, M. D. 2020. COVID economics competitive responses in a devastated industry: Evidence from hotels during COVID-19. SSRN Electronic Journal. https://doi.org/10.2139/ssrn.3660174.

Ogbeide, G. C. 2020. Pandemic (COVID-19) Implications: Recommendations for the events and tourism industry. Events and Tourism Review 3 (2): 32-38. https://doi.org/10.18060/24826.

Pandit, D. and S. Agrawal. 2021. Exploring Challenges of Online Education in COVID $\begin{array}{llll}\text { Times. } & \text { FIIB Business } & \text { Review }\end{array}$ https://doi.org/10.1177/2319714520986254.

Parker, R., J. Bruce, T. Bump, M. Craigie, J. Tapogna, B. Y. Clark, and T. Duy. 2020. Responding to the Economic Impacts of Coronavirus: A Proposed Oregon 
Economic Recovery and Resilience Framework. SSRN Electronic Journal. https://doi.org/10.2139/ssrn.3600629.

Parsoya Shubham and Asif Perwej. 2020. Current needs of making changes in transportation and energy policies to mitigate the bad and harmful impacts of environmental pollution; An Indian perspective. Printing Area, Peer-reviewed International Journal (ISSN: 2394 5303) 01 (63): 83-87. https://doi.org/10.5281/zenodo.4744661.

Parsoya Shubham and Asif Perwej. 2021. Present requirements of drawing up necessary changes in our petroleum usage to alleviate the detrimental aftermath of environmental contamination. The Council of Scientific and Industrial Research (CSIR)National Institute of Science Communication and Information Resources (NISCAIR), Bharatiya Vaigyanik Evam Audyogik. Anusandhan Patrika (BVAAP), NISCAIR Online Periodicals Repository (NOPR) ISSN: 0975-2412 (online), ISSN: $0771-7706$ (print), UGC-CARE Listed Journal, BVAAP 29 (1) June 2021](1): 14-18. https://doi.org/10.5281/zenodo.5317270.

Parsoya Shubham and Asif Perwej. 2021. Strategic industrial business contemplations and prospective marketing approaches of government in controlling and managing the businesses of Oil Marketing Companies (OMCs): An Indian Perspective. In ESN PUBLICATIONS. (An ISO 9001:2015 Registered Company): Vols. ISBN: 978-81-947019-0-3 (Number Special Issue):, pp. 12013-12026). ESN PUBLICATIONS (An ISO 9001:2015 Registered Company). https://doi.org/10.5281/zenodo.4742707.

Parsoya Shubham and Asif Perwej. 2021. Analysis of the role and importance of information and communication technology (ICT) in transforming the present education system of India: with respect to "revised assessment and accreditation framework of NAAC. Langlit, an International Peer-reviewed Open Access Journal (ISSN 2349-5189) Special Issue: 59-66. https://doi.org/10.5281/zenodo.4744288.

Parsoya Shubham and Asif Perwej. 2020. Analysis of the marketing strategies of reliance industries (petroleum and oil company) in enhancing its petroleum business and establishing as a global-level petroleum company. International Joumal of Scientific Research in Engineering and Management (IJSREM) 04 (12): 4. https://doi.org/10.5281/zenodo.4743493.

Parsoya Shubham, Parsoya Priyanka, and Asif Perwej. 2020. Future business prospects and marketing strategies of oil and energy marketing companies (under government of india). Vidyawarta ${ }^{\circledR}$ Peer-reviewed International Journal; Interdisciplinary Multilingual Refereed 
Journal; MAH MUL/03051/2012, (ISSN: 2319 9318) 09 (33): 84-88. (Parsoya S. P., 2020) https://doi.org/10.5281/zenodo.4749296.

Parsoya Shubham and Asif Perwej. 2021. Study of the role and importance of futuristic and fast transportation technology in shaping the bright future of india. Wesleyan Journal of Research | UGC Care-listed | ISSN: 0975-1386 | Peer-reviewed Journal 13 (65) (March 2021): 31-44. https://doi.org/10.5281/zenodo.5329465.

Parsoya Shubham and Asif Perwej. 2021. Study of the Negative and the Positive Impact of Coronavirus Pandemic on Different Types of Industry, Businesses and the Society. Wesleyan Journal of Research | UGC Care-listed | ISSN: 0975-1386 | Peer-reviewed Journal 13 (69): 29-40. https://doi.org/10.5281/zenodo.5336250.

Pass, C. L. and B. Lowes. 1997. Business and microeconomics: an introduction to the market economy. London: International Thomson Business Press.

Pejić Bach, M. 2021. Editorial: electronic commerce in the time of covid-19 - perspectives and challenges. Journal of Theoretical and Applied Electronic Commerce Research 16 (1): IIV. https://doi.org/10.4067/s0718-18762021000100101

Pellegrino, G., F. Ravenna, and G. Züllig. 2020. The cost of coronavirus uncertainty: the high returns to clear policy plans. Australian Economic Review 53 (3): 397-401. https://doi.org/10.1111/1467-8462.12383

Popov, V. 2020. How to deal with a coronavirus economic recession? SSRN Electronic Journal. https://doi.org/10.2139/ssrn.3604351

Rathi, A. and A. Kumar. 2020. Effect of covid 19 on various sectors. International Journal of Trade and Commerce-ILARTC 9 (1). https://doi.org/10.46333/ijtc/9/1/14

Rajiv Desai. 1999. Indian business culture: an insider's guide. Oxford; Auckland; Boston Etc.: Butterworth Heinemann.

Rajput, W. E. 2000. E-commerce systems architecture and applications. Boston: Artech House.

Robinson, C. C. and H. Hullinger. 2008. New benchmarks in higher education: student engagement in online learning. Journal of Education for Business 84 (2): 101-109. https://doi.org/10.3200/joeb.84.2.101-109

Samson, D., T. Donnet, and R. L. Daft. 2018. Management (6th ed.). South Melbourne, Victoria, Australia: Cengage.

Scarborough, N. M. and J. R. Cornwall. 2019. Essentials of entrepreneurship and small business management. New York: Pearson Education.

Siddhu, V. 2020. Post Covid-19: Effects on Automobile Sector in India. International Journal of Trade and Commerce-IIARTC 9 (1). https://doi.org/10.46333/ijtc/9/1/12. 
Singh, G. 2020. E-readiness and customer perception about the e-commerce during lockdown: Covid-19 perspectives. SSRN Electronic Journal. https://doi.org/10.2139/ssrn.3694279.

Shubham, P. 2021. Significance of Technology and Digital Transformation in Shaping the Future of Oil and Gas Industry. Turkish Journal of Computer and Mathematics Education (TURCOMAT). vol. 12, no. 3, Apr. 2021, pp. 3345-52, (Perwej, 2021) https://doi.org/10.17762/turcomat.v12i3.1591.

Snoeyenbos, M., R. F. Almeder, and J. M. Humber. 2001. Business etbics. Amherst, N.Y.: Prometheus Books.

Standing, C. 2000. Internet commerce development. Boston: Artech House.

Stanley, D. and Y. J. Zhang. 2020. Collaborative learning in online business education: Evidence from a field experiment. Journal of Education for Business 95 (8): 506-512. https://doi.org/10.1080/08832323.2019.1703097

Stephen Douglas Acres, C. F. Crouch, J. Grant, and Trenton Charles Watts. 1984. Veterinary Infectious Disease Organization (Saskatoon, Sask). Development and testing of a calf scours coronavirus vaccine. Saskatoon, Sask: Vido.

T Volkan Yuzer and Gulsun Kurubacak. 2010. Transformative learning and online education: aesthetics, dimensions and concepts. Hershey, Pa: Information Science Reference.

Tonny Rutakirwa. 2020. Understanding Corona Virus (Covid-19). S.L.: Lulu Com.

Trevor, J. 2008. Management. Milton, Qld: John Wiley and Sons Australia.

Tripathi, D. 2004. The Oxford History of Indian Business. New Delhi: Oxford University Press.

United Nations 2005. Progress Towards the Millennium Development Goals, 1990-2005, Secretary General's Millennium Development Goals Report. June 13, 2005.

United States. Congress. Senate. Select Committee on Indian Affairs. 1992. Indian Business Opportunities Enhancement Act: report (to accompany S. 3118). Washington, D.C: U.S. G.P.O.

Vineetha, V. 2014. Enhancing the quality of higher education through information and communication technology, Barathi C., Vadivu, P, Lawrence. A.S. (Eds) (280-284) New Delhi: APH Publishing.

Verikios, G. 2020. The dynamic effects of infectious disease outbreaks: The case of pandemic influenza and human coronavirus. Socio-Economic Planning Sciences, 100898. https://doi.org/10.1016/j.seps.2020.100898

Wang Zhou. 2020. Coronavirus prevention handbook. 101 science-based tips that could save your life. S.L.: W W Norton. 
Wheelen, T. L. 2018. Strategic management and business policy: globalization, innovation, and sustainability. New York: Pearson.

Yadav, A. K., S. Ghosh, A. Kotwal, S. Kumar, and S. Bobdey. 2020. Serial antibody response among hospitalized coronavirus disease 2019 cases in India. Medical Journal Armed Forces India. https://doi.org/10.1016/j.mjafi.2020.09.010 